DOI: $10.15290 /$ bsl.2016.08.05

\author{
Katarzyna Sawicka-Mierzyńska \\ Wydział Filologiczny \\ Uniwersytet w Białymstoku \\ e-mail: ka.sias@wp.pl
}

\title{
„Każda rodzina potrzebuje swojego imienia oraz swojej pamięci" - pamięć i zapominanie w literackim obrazie Hajnówki na przykładzie prozy Michała Androsiuka
}

Białoruski pisarz Michał Androsiuk, rocznik 1959, tworzący zarówno w języku białoruskim, jak i po polsku, jest jednym $\mathrm{z}$ najbardziej znanych i lubianych na Podlasiu prozaików - świadczy o tym m.in. dwukrotna nominacja do najważniejszej lokalnej nagrody literackiej (Nagroda Literacka Prezydenta Miasta Białegostoku im. Wiesława Kazaneckiego), której laureatem pisarz został w roku 2011. Całe życie Androsiuka związane jest z trzema miejscami: z rodzinną wsią Wojnówką, położoną tuż przy granicy z Białorusią, z Hajnówką - miasteczkiem na skraju Puszczy Białowieskiej, gdzie się przeprowadził, by zamieszkać „w bloku” (zamiana drewnianego domu na, choćby najmniejsze, mieszkanie w bloku, była do końca lat 80. największą ambicją i wyrazem awansu społecznego Podlasian) oraz z Białymstokiem. W tej przestrzeni rozgrywa się też akcja jego utworów. W artykule omówiona zostanie kwestia - jak się okaże, bardzo złożona - pamięci i tożsamości bohaterów prozy Androsiuka, która pozostaje w ścisłym związku z miejscem (jako exemplum wybrane zostało jedno konkretne - Hajnówka) oraz stanowi ekstrapolację problemów tożsamościowych polskich Białorusinów ${ }^{1}$. Za kontekst posłużą zarówno ustalenia z zakresu badań pamięciologicznych, jak też

\footnotetext{
1 Tego sformułowania, które może się wydawać kontrowersyjne, używam za białostockim socjologiem pogranicza Andrzejem Sadowskim: „Zdaniem Andrzeja Sadowskiego, usytuowanie Białorusinów w Polsce stosunkowo najlepiej oddaje określenie «polscy Białorusini». Podkreśla ono realnie istniejące związki Białorusinów z państwem polskim i jego kulturą (którą tworzyli także Białorusini - A.S.) przy zachowaniu białoruskiej tożsamości narodowej. Rozpowszech-
} 
geopoetyki i - traktowanych bardziej jako myślowa inspiracja, niż badawcza matryca - studiów postkolonialnych.

Jak zauważa Aleida Assmann „Myśląc o pamięci, musimy zacząć od zapominania. [...] Aby coś zapamiętać, o czymś innym musimy zapomnieć" 2 . Badaczka odnosi to stwierdzenie do pamięci jednostkowej, już za chwilę jednak przenosi kategorię zapominania ze sfery doświadczeń indywidualnych na zbiorowe. Okazuje się, że to właśnie zapominanie jest procesem naturalnym, podczas gdy wspólnotowa pamięć (narodowa, regionalna) wymaga celowych zabiegów, troski, inwestowania, powoływania specjalnych instytucji. Zapominanie - przynajmniej czasowe - bywa pożądane, by zbudować konsensus po dramatycznym konflikcie, jest też niezbędne, jak konstatuje Paul Connerton, w sytuacji formowania nowej tożsamości ${ }^{3}$.

Zapomnienie stanowi też punkt wyjścia literackiego obrazu Hajnówki i jej mieszkańców wykreowanego przez Michała Androsiuka. W zakończeniu opowiadania Mateńka Hajnówka czytamy: „Do miasteczek takich jak nasze ludzie nie przesiedlają się ot, tak sobie, z pustymi rękoma. Przychodzą ze wszystkim, co zdołali uzbierać i zapamiętać, i jedynie niektórzy, rozbudzeni trzecim pianiem kogutów, udają, że nie wiedzą w czym rzecz" ${ }^{4}$. Tych „niektórych" będzie jednak całkiem sporo, tak, jakby wzdłuż rogatek miasta toczyła swe wody Lete, mityczna rzeka zapomnienia. Zaludnią oni karty zbioru opowiadań Biały koń, a wśród nich znajdzie się rodzina Sońki, jednej z jego bohaterek, która po śmierci męża przeprowadza się wraz z synami ze wsi do Miasteczka. Znacząca wydaje się decyzja autora, żeby odebrać Hajnówce jej nazwę (podobnie będzie w miniaturze List do Brukseli albo Zabójstwo w miasteczku Tutaj ${ }^{5}$ ) - nie mamy tu bowiem do czynienia z neutralnym zabiegiem

nione określenie «Białorusini w Polsce», zwłaszcza osobom mniej zorientowanym w strukturze narodowościowej Białostocczyzny, sugeruje imigrancki i tymczasowy charakter białoruskiej mniejszości narodowej w Polsce. Nie oddaje istoty jej historycznego, trwałego związku z państwem i kulturą polską" [A. Sadowski, M. Tefelski, E. Mironowicz, Polacy i kultura polska $z$ perspektywy mniejszości białoruskiej w Polsce, w: Kultura dominująca jako obca, red. J. Mucha, Warszawa 1999, s. 62].

2 A. Assmann, Kanon i archiwum, tłum. A. Konarzewska, w: tejże, Między historia a pamięcią. Antologia, red. naukowa i posł. M. Saryusz-Wolska, Warszawa 2013, s. 74-75.

3 M. Karkowska, F. Pazderski, hasło Zapomnienie, w: Modi memorandi. Leksykon kultury pamięci, red. M. Saryusz-Wolska, R. Traba, współpraca J. Kalicka, Warszawa 2014, s. 549.

4 M. Androsiuk, Mateńka Hajnówka, „Czasopis” 2000, nr 5, s. 32. Opowiadanie zostało opublikowane w "Czasopisie” w trzech częściach, w numerach 1, 2 i 5 z 2000 roku. Na temat pamięci Białorusinów, m.in. na przykładzie twórczości Michała Androsiuka, zob. też: D. Zawadzka, Rafa regionu. O przemianach pamięci w literaturze pogranicza polsko-białoruskiego, „Białostockie Studia Literaturoznawcze" 2012, nr 3.

5 M. Androsiuk, List do Brukseli albo Zabójstwo w miasteczku Tutaj, „,noweKartki” 2012, nr 1. 
pseudonimowania miejsca, jak $\mathrm{w}$ tzw. powieściach $\mathrm{z}$ kluczem; ten gest antycypuje problemy $\mathrm{z}$ tożsamością i historią, czyli z samoidentyfikacją: pozostawienie dużej litery (Miasteczko, Tutaj) czyni z tych wyrazów nazwy własne, ale niejako pozbawione właściwości, a tym samym otwierające pole dla swobodnej pracy pamięci i wyobraźni. Można to również potraktować jako element poetyki paraboli, ku której skłania się Androsiuk.

Kiedy zatem Sońka przeprowadza się do Miasteczka, jej synowie zaczynają tracić pamięć, a jeden $\mathrm{z}$ nich przestaje rosnąć:

Od pierwszego dnia w Miasteczku dzieciom Sońki zaczęły się mylić ścieżki. Na początku wszystko wyglądało niewinnie, nawet śmiesznie. Mały Anton wyprawiony do szkoły mimowolnie szedł do lasu. Kola, wysłany do kiosku po chleb, wracał ściskając w palcach żółtą cytrynę. Zaś najmłodszy Saszka zupełnie zapomniał, którą drogą trafić ma do dorosłości.

[...]

Któregoś razu, kiedy Wałodzia [co ważne, ojciec narratora - dop. K.S.M.] zapomniał jak się nazywa i na schodach cudzego domu przesiedział do zmierzchu, dopóki ręce przypadkowych ludzi nie przygarnęły go, Sońka przestraszyła się naprawdę.

- No jak się nazywasz? Przypomnij sobie. Przecież tak nazywał się twój ojciec, dziad i twój prapradziad. [...]

- Nie wiem, nie wiem kim jestem ${ }^{6}$.

Jak interpretować tę utratę pamięci? Czego dotyczy? Czy można potraktować ją jako gest wyparcia/zaparcia się siebie - przypomnijmy obraz trzykrotnego piania kogutów, ewidentnie odnoszący się do biblijnego pierwowzoru: „Zanim kogut zapieje, trzy razy się Mnie wyprzesz". Aby udzielić odpowiedzi na te pytania, należy odwołać się do kontekstu, jakim jest tożsamość narodowa autora. Androsiuk, o pokolenie młodszy od duchowego patrona polskich Białorusinów, Sokrata Janowicza, w pełni identyfikuje się ze swoją białoruskością, działa na rzecz białoruskiej społeczności, nie należy jednak do grona tzw. Białorusinów walczących, ani nie traktuje swej twórczości jako oręża tej walki. Problem polonizacji, obumierania języka jest w jego prozie subtelnie tematyzowany, to raczej przesycony melancholią zapis nieuchronnych procesów niż próba ich powstrzymania: „Dziadka Uładzimira, który utargował u sowieckiego kapitana niewielki skrawek kraju swoich białoruskich dziadków, by przekazać go krajowi swoich polskich wnuków, nie poznałem nigdy"7. O tym, że rzecz dotyczy Białorusinów, świadczą imiona

\footnotetext{
6 M. Androsiuk, Biały koń, przeł. M. Rębacz, Białystok 2011, s. 42, 44-45.

7 Tamże, s. 23.
} 
bohaterów, ich wyznanie (są prawosławni), miejsce akcji (w Hajnówce i okolicznych wsiach Białorusini stanowią większość), wreszcie, w przypadku Białego konia, język - napisał go Androsiuk po białorusku. Wypieranie się przeszłości na rogatkach Miasteczka może mieć też jeszcze jeden aspekt: Hajnówka to dziś symboliczne centrum konfliktu pamięci, który dotyczy wydarzeń z 1946 roku i mordów, jakich dokonał na mieszkańcach okolicznych wsi oddział „Burego" (Romualda Rajsa). Kiedy powstawał Biały kon, nie była to jeszcze sprawa tak upubliczniona - pamięć o tej tragedii zachowała się na poziomie tabuizowanych wspomnień rodzinnych i w archiwach, czyli poza obiegiem pamięci funkcjonalnej, poza regionalnym kanonem. Najwygodniej było zostawić ją za sobą.

Dysponując tą wiedzą, możemy inaczej spojrzeć na obraz Wałodzi, Saszy, Koli i Antona, którzy zapomnieli o tym, kim i gdzie są. Zatraca też chyba w tym przypadku swą wyrazistość zaproponowany przez Aleidę Assmann podział na zapominanie aktywne i bierne - przypomnijmy:

Aktywne zapominanie jest wynikiem zamierzonych czynności, takich jak wyrzucanie na śmietnik lub niszczenie. Samo zapominanie to niezbędna i konstruktywna część wewnętrznych transformacji społecznych, ale gdy kieruje się je na inne kultury lub prześladowane mniejszości, staje się aktem destrukcyjnej przemocy. [cenzura, np. - dop. K.S.M.] [...] Bierna forma kulturowego zapominania odnosi się do niezamierzonych czynności, takich jak utrata, ukrycie, rozproszenie, zaniedbanie, porzucenie lub pozostawienie ${ }^{8}$.

W literackim ujęciu Androsiuka na pozór wygląda to tak, jakbyśmy mieli do czynienia z zapominaniem naturalnym, biernym, mimowolnym - wraz ze zmianą miejsca i stylu życia po prostu coś się traci, zostawia, wiemy jednak, że to "zaniedbanie", by użyć pojęcia Assmann, jest stymulowane kontekstem politycznym, historycznym i społecznym. To nie jest cenzura, jedno z kluczowych narzędzi presji zapominania, nikt nie zabrania rozmawiać po białorusku, a nawet wydawać w tym języku książek, a jednak dokonuje się proces samopolonizacji, który na użytek tych rozważań można określić mianem „samozapominania”. Jest to ten moment, kiedy "pamięciologia” spotyka się z dyskursem postkolonialnym. Bardzo istotne wydaje się związane z tym mariażem „uprzestrzennienie pamięci”. Jak zauważa Dorota Kołodziejczyk: „Uprzestrzennienie pamięci - jej wielokierunkowość i zmienność w przestrzeni geograficznej i kulturowej - dokonuje się nie tylko jako nowa formuła krytyczna, ale przede wszystkim jako realny proces w kształtowa-

\footnotetext{
8 A. Assmann, Kanon i archiwum, s. 75.
} 
niu się tożsamości w sytuacji migracji i diaspory" ${ }^{\prime 2}$. W przypadku Podlasia chodzi nie tylko o przenoszenie się ludności ze wsi do miast, ale także o - jakże istotne w Białym koniu i Wagonie drugiej klasy, pierwszej polskiej powieści Androsiuka - przesuwanie granic państwowych, w wyniku którego, nie zmieniając miejsca zamieszkania, doświadcza się przemieszczenia kulturowej, historycznej i politycznej czasoprzestrzeni (państwo to przecież nie tylko obszar, ale też historia - czas). Oba te procesy stymulują przemiany pamięci. Warto też zwrócić uwagę, że narrator cytowanego wyżej opowiadania oddaje proces zapominania poprzez obrazowanie przestrzenne - gubienia się i mylenia ścieżek.

Kreując, by posłużyć się określeniem Elżbiety Rybickiej ${ }^{10}$, miejsce „wydrążone z pamięci", doprowadzając swoich bohaterów do stanu całkowitej amnezji (czym innym jest bowiem zapomnienie własnego imienia), Androsiuk we właściwy sobie, metaforyczno-paraboliczny sposób prezentuje trzy strategie jego przezwyciężania, przy czym każda z nich, jak się za chwilę przekonamy, okaże się zawodna, niewystarczająca i nosić będzie znamiona pamięci fałszywej.

Pierwsza zawiera się w mitycznej opowieści Sońki o dziwnym drzewie, z którego, po uderzeniu pioruna, wychodzą Sonia i Uładzimir - „to oni dali początek naszemu Miasteczku i naszej rodzinie" ${ }^{11}$. Sońka:

Wymyśliła ją w potrzebie chwili od pierwszego do ostatniego słowa, świadomie nie zważając na prawa fizyki, historii i przyrody, ponieważ każda rodzina potrzebuje swojego imienia oraz swojej pamięci, i są one ważniejsze niż wszystko inne, nawet to, co jest potwierdzone przez naukę ${ }^{12}$.

Potrzeba posiadania spójnej tożsamości (a jej gwarantem jest pamięć) jest tu silniejsza od imperatywu jej prawdziwości. Mityczna opowieść zdaje się też odpowiadać pragnieniu całości, jedności, pełni, artykułowanemu przez narratora, którego nie zadowala tradycyjnie pojmowana historia - jej symbolem jest muzeum: "Czas w muzeum nie płynie żywym strumieniem i jest tam wystawiony na widok w osobnych, jakby zamrożonych fragmentach, najważniejszych dla tych, którzy w danej chwili rządzą światem"13. Ożywcza, sca-

9 D. Kołodziejczyk, Postkolonialne odzyskiwanie pamięci: zawtaszczenia, fabulacje, niesamowite odpominanie, w: Od pamięci biodziedzicznej do postpamięci, red. T. Szostek, R. Sendyka, R. Nycz, Warszawa 2013, s. 281-282.

10 E. Rybicka, Topografie historii: miejsce, pamięć, literatura, w: tejże, Geopoetyka. Przestrzeń i miejsce we wspótczesnych teoriach i praktykach literackich, Kraków 2014, s. 312-314.

11 M. Androsiuk, Biały koń, s. 45.

12 Tamże, s. 46.

13 Tamże, s. 40-41. 
lająca moc mitu stanowi totalne przeciwieństwo „zamrożonych", martwych fragmentów przeszłości.

Warto przyjrzeć się bliżej drzewu, osi świata Sońki, która miałaby stać się tożsamościowym punktem odniesienia dla jej synów. Otóż jest ono tworem "transgatunkowym" - poszczególne rodzaje drzew: dąb, sosna, buk, brzoza przenikają się nawzajem, każde wnosi swoje właściwości, ale też nie można ich rozdzielić, oznaczyć, gdzie zaczyna się jedno, a kończy drugie. Być może stanowi ono symbol "tutejszości", tożsamości, z którą identyfikowało się wielu mieszkańców Podlasia na początku XX wieku (do dziś ma swoich admiratorów, jak też zagorzałych przeciwników, traktujących ją jako wyraz tchórzliwego wypierania białoruskości - to bardzo złożony temat, nie będę go tu rozwijać $\left.{ }^{14}\right)$. Można je też jednak potraktować jako symboliczny wyraz (zresztą jedno drugiego nie wyklucza, wręcz przeciwnie) transkulturowości pamięci, do której nawołuje Ewa Rewers we fragmencie Post-polis o bardzo znaczącym tytule: Więcej pamięci - ku transkulturowości („,więcej pamięci" oznacza tu odejście od homogenicznych, wyłącznie narodowych narracji o przeszłości): „Transkulturowość jest wszakże rodzajem antyutopii konsekwencją pogodzenia się z nieobecnością czystej, należącej tylko do nas pamięci, w której nie ma jednak miejsca dla nostalgii za utraconą homogenną "naszością»"15. Assmann nazwie podobne zjawisko „dialogicznym pamiętaniem"16, Rybicka, za Robertem Trabą, będzie pisała o „polifonii pamięci"17. Co ważne, wszystkie przywołane badaczki traktują te kategorie jako rodzaj postulatu, stan pożądany, lecz trudny do osiągniecia. Tak pointuje swoje rozważania autorka Geopoetyki:

Przywołuję propozycję Domańskiej [m.in. z tekstu Epistemologia pograniczy], ponieważ wskazuje ona na zasadniczy dylemat polifonii pamięci $\mathrm{w}$ regionach pogranicznych - napięcie pomiędzy agonem a wspólnotą. Dylemat - jak sądzę na razie nierozstrzygalny, a rozwiązywany obecnie najczęściej w duchu mikro-utopii, czy też „słabej” utopii wspólnotowej ${ }^{18}$.

$14 \mathrm{Na}$ temat tutejszości podlaskiej zob. D. Zawadzka, O byciu przemieszczanym. "Tutejszość" podlaska w perspektywie transgranicznej, w: Region a tożsamości transgraniczne, red. D. Zawadzka, M. Mikołajczak, K. Sawicka-Mierzyńska, Kraków 2016.

15 E. Rewers, Post-polis. Wstęp do filozofii ponowoczesnego miasta, Kraków 2005, s. 191.

16 „W takim związku państw jak Europa dialogiczne pamiętanie niesie ze sobą szczególne możliwości. Dzięki wzajemnemu zbliżeniu mogłoby ono w przyszłości rozszczelnić granice monolitycznych pamięci narodowych i wzmocnić transnarodową integrację poprzez bardziej zróżnicowane i kompleksowe konstrukcje pamięci" [A. Assmann, Od zbiorowej przemocy do wspólnej przyszłości, przeł. J. Kalicka, w: tejże, Między historia a pamięciq, s. 272].

17 E. Rybicka, Czy możliwa jest „polifonia pamięci” w literackich badaniach regionalnych?, w: tejże, Geopoetyka. Przestrzeń i miejsce we wspótczesnych teoriach i praktykach literackich, s. 353-354.

18 Tamże, s. 361. 
Mityczne drzewo uznać można za rodzaj takiej przednowoczesnej „mikro-utopii", która umiera wraz z jej autorką, w świecie, którego sama Sońka już nie rozpoznaje.

Druga strategia przywracania pamięci wiąże się z pismem (literaturą?):

Wałodzia tę opowieść [matki - dop. K.S.M.] zapisał, przyodziawszy w porównania i epitety. Miał zeszycik w kratkę, trzydziestodwukartkowy, który od tego dnia szybko zaczął zapełniać. Trafiały do niego wszystkie dni, wszystkie słowa i wszystkie myśli. Zapisawszy pierwszy zeszycik pisał w kolejnym. Z czasem nazbierało się ich nieprawdopodobnie dużo, zajęły wszystkie szuflady; leżały na stole, półkach, spadały na podłogę, przez kuchnię i sień wychodziły na schody, podwórko i dalej na najbliższe uliczki. Nie udawało się ich ominąć, ale dawały po sobie stąpać niczym po znajomych śladach. Kartki zapisywane w pierwszych zeszycikach przypominały drzewo, z którego powstało miasteczko ${ }^{19}$.

Kiedy jednak po latach Wałodzia wróci do swoich zapisków, nie rozpozna w nich przeszłości: „Tak nie było, bo nie mogło tak być. Po co więc ja to zapisałem?" 20 - będzie powtarzał, by wreszcie spalić wszystkie zeszyty. Naturalny kulturowy proces (proszę wybaczyć oksymoron): zastąpienie mitycznej, oralnej historii kroniką, ulega tym samym przerwaniu, „ślad" przeszłości, który staje się - by posłużyć się tu terminem Mariusza Wilka - „tropą", po jakiej mogłyby stąpać kolejne pokolenia, ulega zniszczeniu.

W znakomitej powieści Toni Morrison Umiłowana, którą Dorota Kołodziejczyk omawia jako przykład postkolonialnego odzyskiwania pamięci, tytułowa bohaterka/widmo pozostawia ślady dopasowujące się do stawianej na nich stopy: „Ślady - żeby były istotne, musi ktoś po nich stąpać. «Ale wystarczy unieść stopę, a ślady znowu znikają»"21. Zapewne zatem stało się tak - by powrócić do prozy Androsiuka - że po śladach stworzonych przez Wałodzię przestano stąpać, a przestano po nich stąpać, gdyż jego tutejszo-białoruska, inspirowana mitem transkulturowości opowieść, nie mieści się w dominującej, historycznej, narodowej narracji. To właśnie zgodnie z jej autorytetem "nie mogło być" to, co przecież się wydarzyło, a nawet zostało spisane. Stworzona przez Wałodzię literatura - były tam przecież epitety i porównania, a matka zwracała się do niego "mój ty pisarzu” - nie weszła,

\footnotetext{
19 M. Androsiuk, Biały koń, s. 46.

20 Tamże, s. 115.

21 D. Kołodziejczyk, Postkolonialne odzyskiwanie pamięci: zawłaszczenia, fabulacje, niesamowite odpominanie, s. 296.
} 
zgodnie z terminologią Astrid Erll22, do obiegu cyrkulacji pamięci. Jak zauważa Aleida Assmann, to, co wykracza poza „perspektywy i pozycje” pamięci narodowej, z jej ścisłymi regułami podziału ról, np. na ofiary i oprawców, „W ogóle nie może stać się przedmiotem akceptowanej narracji lub staje się nim jedynie $\mathrm{z}$ wielkim trudem i z tego powodu zostaje przeważnie oficjalnie "zapomniane» ${ }^{23 "}$.

Wołodzia wybiera zatem trzecią strategię - pamięć fałszywą, ale usytuowaną w mocnym, kulturowym kontekście, jednolitą i nobilitującą: szlachecką polskość. Odkrywa ją poprzez pismo, ale nie są to własne notatki, tylko biblioteczka żony, noszącej kapelusze i egzotyczne imię Stefania Polki, którą przywiózł do Miasteczka z prawdziwego miasta.

Spaliwszy wszystkie swoje zeszyciki, przeszedł na półki Stefanii.

[...] świat, zapisany w książkach Stefanii, dodawał Wałodzi dziwnej siły. Zaczął uważać się za stwórcę, jedynego w swoim rodzaju rzeźbiarza, który nie $\mathrm{z}$ drewna, nie z gliny, ale $\mathrm{z}$ nieznanej, prawiecznej materii wycina siebie samego, swoją własną postać. Obdarowuje ją życiem i potrafi natchnąć losem.

[...]

- Jeszcze nie rozwiązano wszystkich zagadek, jeszcze drzemią w dalekiej przeszłości sprawy ogarnięte czarnym płaszczem zapomnienia. Jeśli nie obudzi się ich $\mathrm{w}$ tej chwili, nie wyprowadzi się na świeże powietrze, pozostaną tam na zawsze ${ }^{24}$.

Jest to więc pamięć fałszywa, nosząca pozory odpominania - Wałodzia, dopatrzywszy się w swoich oczach podobieństwa do "Stasiczka", młodego panicza Drohobyckiego, kreuje historię (status jej prawdziwości pozostaje $\mathrm{w}$ zawieszeniu - jest to przecież opowieść prawdopodobna, mająca wiele rzeczywistych pierwowzorów), w której młoda, piękna Sońka miała romans z dziedzicem, a gdy zaszła w ciążę, wydano ją za mąż za woźnicę Uladzimira, ofiarowując mu, w ramach rekompensaty, pięknego konia. Owładnięty swoją wizją zaczyna "przypominać” sobie przedwojenny świat, w pełni identyfikując się z Drohobyckimi i ich kulturowym dziedzictwem, które, znowu za sprawą odkrywanych na portretach czy fotografiach podobieństw oraz niepotwierdzonych pogłosek, wyprowadza aż z rodu Sapiehów. Wałodzia, osuwający się coraz głębiej w świat wyobraźni pomieszanej z pamięcią, traci kontakt z rzeczywistością i rodzinę - żona go opuszcza, zabierając ze sobą syna.

22 Zob. A. Erll, Literatura jako medium pamięci zbiorowej, przeł. M. Saryusz-Wolska, w: Pamięć zbiorowa i kulturowa. Wspótczesna perspektywa niemiecka, red. M. Saryusz-Wolska, Kraków 2009, s. 212-247.

23 A. Assmann, Od zbiorowej przemocy do wspólnej przyszłości, s. 267.

24 M. Androsiuk, Biały koń, s. 123, 124, 126. 
Jak zauważają autorzy hasła „Pamięć fałszywa” w leksykonie Modi memorandi,

Fałszywe wspomnienia pojawiają się w związku z psychologicznym mechanizmem myślenia kategorialnego, tj. posługiwania się stereotypami w postrzeganiu siebie i innych. Często nieistniejące przeszłe wydarzenia uważamy za prawdziwe tylko dlatego, że są zgodne z posiadanym stereotypem, co może zasadniczo wpływać na struktury pamięci zbiorowej ${ }^{25}$.

Determinowany zinterioryzowanym stereotypem, sytuującym białoruskość/tutejszość po stronie gorszości, chłopskości („mużyckości”, jak się mówi po białorusku), Wałodzia woli być zatem bękartem Drohobyckich niż potomkiem Uladzimira Iwaniuka.

Jak zauważa Katarzyna Szalewska, tworzenie apokryficznych czy fałszywych tożsamości (a zatem także pamięci) jest symptomatyczne dla literatury polskiej XX i XXI wieku, zmagającej się z wyzwaniem literackiego przetworzenia/odtworzenia historycznych traum, do jakich należy nie tylko wojna, ale też okres PRL-u, który, siłą rzeczy, a raczej cenzury i polityki kulturalnej państwa, nie mógł być w sztuce reprezentowany na bieżąco. Odtwarzanie przeszłości w oczywisty sposób staje się też pisaniem historii miejsc, kreacją konkretnych przestrzeni:

Interpretacja dziejowej traumy tworzona w perspektywie spacjalnej ujawnia dychotomiczną taktykę amnezji i teatru pragnienia, by przeszłość uobecnić. Jeśli posłużyć się tak często przywoływaną $\mathrm{w}$ kontekście urban studies metaforą palimpsestu, to współczesna literatura polska stanowi tu przykład szczególnie wielowarstwowego pisma, kolażu skonstruowanego z cięć, nieczytelności i powstających $\mathrm{w}$ ich miejsce apokryfów oraz fałszywych tożsamości [wyróżnienie - K.S.M.]. Zapomnienie i restytucja, jako antynomia immanentnie związana $\mathrm{z}$ żywiołem miejskim, $\mathrm{w}$ reprezentacjach literackich okazuje się tym samym symptomem posttraumatycznego zespołu wyparcia i terapii. Strata, wpisana w miejską przestrzeń w XX stuleciu, nie może zostać przepracowana, co powoduje dezintegrację percypującego podmiotu. Ten wstrząs musi prowadzić do wyparcia, jakim jest kulturowa amnezja, pozornej żałoby, jaką jest jej instytucjonalizacja $\mathrm{w}$ postaci miejsca pamięci, lub semiotyzacji, jaka dokonuje się wokół obiektu utraty - i to właśnie na tej ostatniej płaszczyźnie najmocniej pracuje literatura ${ }^{26}$.

25 M. Bilewicz, A. Stefaniak, hasło Pamięć fałszywa, w: Modi memorandi, s. 325.

${ }^{26}$ K. Szalewska, Antropologia przestrzeni miejskiej w kontekście polskiego dyskursu postzależnościowego, w: (P)o zaborach, (p)o wojnie, (p)o PRL. Polski dyskurs postzależnościowy dawniej i dziś, red. H. Gosk, E. Kraskowska, Kraków 2013, s. 352-353. 
Narracje mniejszościowe można zatem uznać za - oczywiście specyficzną i zdeterminowaną wieloma dodatkowymi czynnikami, wynikającymi z sytuacji zagrożenia i podporządkowania - odmianę tego zjawiska.

Jest jednak jeszcze w Białym koniu wnuk Sońki, syn Wałodzi i Stefanii o znaczącym imieniu Michał, pierwszoosobowy narrator tych opowiadań, który wyznaje $\mathrm{w}$ pierwszym $\mathrm{z}$ nich:

Zostawiając za plecami Białystok wyobrażam sobie ciepłe uliczki Miasteczka. Przecinam je nie zatrzymując się, bo zgubiłem tu wiele z tego co było mi bliskie, i skoro nie można odzyskać wszystkiego w całości, nie widzę sensu w odszukiwaniu jakichś oddzielnych fragmentów ${ }^{27}$.

Narrator wprawdzie nie przekracza granic Miasteczka fizycznie, ale wraca do niego pamięcią i wyobraźnią (zbiór opowiadań stanowi zapis tej podróży), zdając sobie przy tym sprawę z tego, że - powtórzmy, bo to kluczowe słowa: „nie można odzyskać wszystkiego w całości”. Wydaje się, że nie chodzi tu tylko o naturalną $\mathrm{w}$ procesie przypominania redukcję, utratę, ale o świadomość, że pamięć mniejszości zawsze będzie miała charakter przekładu, a więc będzie pamięcią nieco zafałszowaną, w której nie można dotrzeć do „czystego" pierwowzoru. „Mimikra jako przekład, przekład zaś jako strategia przeżycia to trzy wzajemnie się warunkujące strategie postkolonialnej pamięci kulturowej" 28 - konstatuje Dorota Kołodziejczyk. Trzy przykłady tej mimikry, nazwane przeze mnie strategiami pamięci, zostały wyżej omówione: mit, kronika/osobiste świadectwo, historia narodowa. Wszystkie one zawiodły. Została jednak również książka Androsiuka, która wykazuje związki z pamięcią przede wszystkim w dwóch, wyróżnionych przez Astrid Erll, obszarach: jako pamięć $\mathrm{w}$ literaturze (kwestia pamięci jest tu przecież wyraźnie tematyzowana) oraz medium pamięci, gdyż wprowadza do regionalnego obiegu pamięć Białorusinów, paradoksalnie - jako niepamięć; uruchamia też - by posłużyć się sformułowaniem Rybickiej - „cyrkulację określonych wyobrażeń regionu" ${ }^{29}$. Wydaje się, że Androsiuk - trudno orzec, na ile świadomie, ale nie ma to większego znaczenia - próbuje udzielić odpowiedzi na pytanie, które stawia, analizując pamięć z perspektywy podmiotu postkolonialnego, Kołodziejczyk:

\footnotetext{
27 M. Androsiuk, Biały koń, s. 6-7.

28 D. Kołodziejczyk, Postkolonialne odzyskiwanie pamięci: zawłaszczenia, fabulacje, niesamowite odpominanie, s. 292.

29 E. Rybicka, Czy możliwa jest „polifonia pamięci” w literackich badaniach regionalnych?, s. 356.
} 
jak z rzeczy utraconych uzyskać nową jakość, jak budować tożsamość na poczuciu dziedzicznie utraconej tożsamości (tożsamości „rdzennej” podmiotu kolonialnego, tożsamości kolonialnej mimikry odrzucanej zarówno przez nowy, postkolonialny nacjonalizm, jak i przez byłe imperium), jak pamiętać odpowiedzialnie - krytycznie, ale też rozwijając umiejętność radzenia sobie z emocjami nieuchronnie łączącymi się z procesem przypominania/pamiętania - melancholią, traumą, resentymentem czy nostalgią ${ }^{30}$.

W Wagonie drugiej klasy, powieści napisanej w języku polskim i wydanej w 2010 roku, więc de facto powstałej później niż Biały koń (białoruski pierwowzór tego zbioru opowiadań pochodzi z 2006 roku), kwestia relacji oficjalnej, „wielkiej” Historii oraz lokalnych, a ściślej pogranicznych narracji o przeszłości i pamięci prywatnej, rodzinnej, jest problematyzowana wprost, jako jeden z kluczowych wątków książki. Hajnówka występuje tu już nie pod szyldem "Miasteczka”, ale ze swoim autentycznym toponimem, a już sam tytuł sugeruje, że ważnym „bohaterem” będzie kolej - w rzeczy samej akcja koncentruje się wokół małego dworca, na którym narrator całej opowieści Stefan pracuje jako bileter (w oczywisty sposób odsyła nas to do klimatu Pociagów pod specjalnym nadzorem Bogumila Hrabala i ich filmowej ekranizacji, zwłaszcza że w obu przypadkach istotnym motywem jest miłość). Androsiuk, mając świadomość, że - przypomnijmy - nie można odzyskać wszystkiego w całości, skupia się na wycinku historii miasteczka ujętym klamrą otwarcia i likwidacji dworca kolejowego. Oczywiście wiąże się to z szeregiem konsekwencji, nie tylko w wymiarze biografii tracących pracę bohaterów dworzec/stacja kolejowa to także obecność Hajnówki w rozkładach jazdy, jej łączność ze światem, potwierdzenie ważności (przyjeżdżają tu przecież nawet pociągi z dalekiej Warszawy, z których wysiadają inni, „kolorowi” ludzie), przydatności, gospodarczego potencjału. Dworzec jest zatem jedynie „soczewką" skupiającą sieć znaczeń związanych z koleją. Karl Schlögel proponuje, by spojrzeć na rozkłady jazdy pociągów (wydaje się, że warto objąć tą sugestią także dworce, linie kolejowe, wszystko, co rozkłady jazdy w sobie metonimicznie zawierają) jak na "protokoły cywilizacji”:

Rozkłady jazdy są czymś w rodzaju podstawowych książek na temat funkcjonowania naszej kultury.

To nie tylko tabele i spisy treści, lecz także choreografie nieskończenie wielu skorelowanych ze sobą poruszeń; protokoły ruchu, bez którego tak oczywista dla nas rutyna cywilizacji zawaliłaby się w ciągu jednego dnia. Słowem, to nie

30 D. Kołodziejczyk, Postkolonialne odzyskiwanie pamięci: zawtaszczenia, fabulacje, niesamowite odpominanie, s. 293. 
tylko rozkłady jazdy, raczej kroniki dokumentujące proces opanowywania przestrzeni, protokołujące postęp w dziedzinie skracania dystansów i zagęszczania przestrzeni. Jeśli rozkłady jazdy gdzieś się nie ukazują, jest to oznaka defektu zasadniczej wagi, a nawet upadku. Ich nieobecność to najlepszy symbol epok chaosu, w których króluje nie rozkład jazdy, a improwizacja ${ }^{31}$.

Nie bez znaczenia dla naszych rozważań pozostaje fakt, że niemiecki badacz jako jeden z ważnych „protokołów cywilizacji” wymienia rozkłady jazdy kolei Cesarstwa Rosyjskiego.

Wojciech Tomasik konstatuje, że „podobnie jak u schyłku XVIII w. balon, tak w połowie następnego stulecia kolej miała dokumentować potęgę ludzkiego umysłu i cywilizacyjny postęp" ${ }^{\prime 2}$, zaś:

w latach 70. i 80. XIX w. metafora życie-droga żelazna wyraża wiarę, że człowiek może zapanować nad przyrodą i świadomie kształtować własny los. [...] Pędząca lokomotywa zaczyna funkcjonować jako współczynnik inteligibilności dziejów. Staje się symbolem historii współtworzonej przez człowieka ${ }^{33}$.

Tę optymistyczną wizję zmieni i zweryfikuje oczywiście wiek XX (abstrahuję też tutaj, gdyż nie to stanowi główny przedmiot analizy, od ambiwalentnego stosunku romantyków wobec kolei, która miała zniszczyć etos i metafizyczny wymiar podróżowania). Jednak ani Schlögel, ani Tomasik nie eksponują faktu - być może traktując go jako oczywiste założenie - iż "rozkłady jazdy” to protokoły pisane przez imperia, uwzględniające przede wszystkim ich interesy. Znakomicie natomiast wygrywa ten aspekt kolei (traktowanej jako pewna metafora, może nawet właśnie metafora wielkiej Historii) Androsiuk: linia kolejowa pojawia się w Hajnówce za sprawą cara, który każe ją wybudować w celach militarnych, na potrzeby wojny, zaś znika (oczywiście nie fizycznie - tory nadal będą biegły, tyle że już donikąd nie prowadząc) w momencie wstąpienia Polski do Unii Europejskiej (a więc niejako jej decyzją), symbolizującej Zachód, globalizację, makroekonomię - wielki świat, przesądzający ze swoich wyżyn o losach "maluczkich”. Jak twierdzi Schlögel, zniknięcie danych połączeń kolejowych i rozkładów jazdy oznacza koniec pewnej epoki ${ }^{34}$, w Wagonie drugiej klasy - koniec pewnego świata. Androsiuk ogłasza go, kreśląc przejmujący obraz piasku zasypującego dworzec:

\footnotetext{
31 K. Schlögel, W przestrzeni czas czytamy. O historii cywilizacji i geopolityce, przeł. I. Drozdowska, Ł. Musiał, posł. H. Orłowski, Poznań 2009, s. 350-351.

32 W. Tomasik, Ikona nowoczesności. Kolej w literaturze polskiej, Wrocław 2007, s. 18.

33 Tamże, s. 24.

34 K. Schlögel, W przestrzeni czas czytamy. O historii cywilizacji i geopolityce, s. 358.
} 
Słyszę, jak piasek sączy się przez sufit do biura pana zawiadowcy, do kasy biletowej, do poczekalni, grubym dywanem zalega na posadzce, osiada na ścianach szarym kurzem i tłumi tykanie dworcowego zegara. Brnę po kostki w piachu, otwieram drzwi na peron ${ }^{35}$.

Koniec oznacza jednak również wyzwalający początek: Stefan, wyzerowawszy datownik, zabiera z kasy i „,upycha pod ubraniem” mnóstwo biletów, dzięki którym będzie mógł „dojechać do każdego miejsca na świecie” ${ }^{36}$, być może po raz pierwszy sam decydując o jego wyborze. Dzieje się zatem tak, jakby odzyskanie wolności było możliwe pod warunkiem bycia zapomnianym, porzuconym przez „imperia”, „centra”, a więc - wyłączonym z Historii. Wtedy też można próbować spisać własną opowieść, przeciw-historię. Tak czyni obdarzony niezwykłą pamięcią (obejmuje nawet dzień narodzin), wzbogaconą wspomnieniami przodków i bujną wyobraźnią, Stefan, mający zresztą pełną świadomość rangi tego aktu:

- To przecież koniec świata!

[...]

Tak mówią ci, którzy trafili tu pierwszy raz, albo zupełnie przypadkowo. Jutro wyjdą na peron w jakimś innym mieście, a pojutrze zapomną o dzisiejszym dniu. Więc to miejsce wygląda im jedynie na koniec świata. Dla mnie jest początkiem świata. Należę do niego, a on do mnie. Nawet te gołębie, które teraz podchodzą do ławeczki, a ja rzucam im pokruszony chleb. Dałem im imiona i napisałem historię, więc należą do mnie [wyróżnienie - K.S.M.] ${ }^{37}$.

Stefan (Michał Androsiuk?) musi więc spisać i pozostawić po sobie historię Hajnówki, bo w przeciwnym razie zawłaszczy ją ktoś inny. Pytanie narratora: „Czy warto [...] przywoływać tu mały dworzec kolejowy w małym mieście? Czy należy wspominać o restauracji «Dworcowa», wzniesionej na potrzeby kilkudziesięciu podróżnych?"38 traktować wypada zatem jako retoryczne. Jak zauważa Astrid Erll:

Teksty literackie przyjmują rolę mediów negocjacji w wypadku konkurencji pamięci, tworząc przeciw-pamięci - na przykład wówczas, gdy przedstawiają pamięć grup marginalizowanych lub inscenizują hierarchie wartości i samooceny inne niż te, które dominują w kulturze pamięci ${ }^{39}$.

\footnotetext{
35 M. Androsiuk, Wagon drugiej klasy, Białystok 2011, s. 129.

36 Tamże.

37 Tamże, s. 40-41.

38 Tamże, s. 113.

39 A. Erll, Literatura jako medium pamięci zbiorowej, s. 239.
} 
Można powiedzieć, że świadomość istnienia napięcia między Wielką Historią a losem indywidualnym czy dziejami małych społeczności, mniejszości i większości Stefan dziedziczy po swoim dziadku, szewcu Ściopce/Stiepanie/Stefanie, który po latach służby wojskowej oświadcza carowi:

- Wybacz, Mikołaju Drugi. Już nic tu po mnie - dziadek nagle przypomniał sobie, że wcale nie jest jakimś tam Stiepanem Grigorijewiczem, ale zwyczajnym Ściopką spod Puszczy Białowieskiej. I nie musi tworzyć historii na użytek tłustych profesorów i ich niedożywionych studentów. Odrzucił karabin w głęboki śnieg, wsiadł do pociągu i wrócił do siebie. Wyszedł z wagonu na naszym maleńkim dworcu, przeszedł peron, przedarł się przez akacjowe zarośla i stanął jak wryty. Pod jego nieobecność osada rozrosła się w miasteczko, wokół miasteczka, daleko na zachód, na północ i na południe wyrósł kraj, o którym już od dawna tu nie słyszano. Polska. Chcąc nie chcąc, został więc w tej Polsce panem Stefanem, szanowanym szewcem $[\ldots]^{40}$.

Ten fragment sugeruje również, że - by powrócić do Białego konia i słów Sońki, które zostały zawarte w tytule tych rozważan - fundamentem ludzkiej tożsamości jest, obok pamięci, imię. W przypadku mieszkańców pograniczy okazuje się to jednak dość chwiejny punkt odniesienia, gdyż kolejni twórcy Historii nadają jej bohaterom, także tym drugo- czy trzecioplanowym, własne imiona. W ten sposób "tutejszy" Ściopka, ukończywszy 19 lat, został Stiepanem, potem w Polsce - Stefanem, podczas krótkotrwałej okupacji Hajnówki przez Sowietów - znowu Stiepanem, a potem, ponownie jako Stefana, zabili go Niemcy za to, że Sowietom, zgodnie ze swoja profesją, szył buty. Bycie szewcem wydaje się tu trwalszym i ważniejszym atrybutem niż imię, a czynność robienia butów staje się metonimią peryferyjno-centralnych relacji i kolejnym (po transgatunkowym drzewie) symbolem „tutejszości”. Pierwsza para butów zrobiona przez Antoniego, syna Ściopki i ojca narratora, mogła należeć zarówno do białoruskiego partyzanta, który nie chciał się pogodzić z postanowieniami traktatu ryskiego, „dzielącymi Białoruś między

40 Tamże, s. 12. W tym miejscu warto też przywołać niezwykle urokliwą scenę, gdy wezwany do wojska Ściopka który nie wie, z kim ma walczyć, postanawia, przejeżdżając pociągiem przez Petersburg, zapytać o to samego cara: „- To ja, Ściopka z Białowieży! Jadę z odsieczą, Mikołaju Drugi Romanow!

- Wiem, gdzie jest Białowieża. Mam tam swój pałac [...].

- Wlejemy, carze. Tylko powiedz, komu? [...]

- A wszystkim, rekrucie Stiepanie Grigorijewiczu, zdrowo wlejcie. Wszystkim, kto się nawinie pod rękę. Potem będziemy tłumaczyć się jakiejś tam międzynarodowej opinii publicznej". Tamże, s. 10-11. Konfrontowanie "maluczkich” z wielkimi tego świata i prowincji z centrum, z ośrodkami światowej władzy należy do stałych elementów prozy Androsiuka. Nie ma tu żadnych ogniw pośrednich, między Hajnówką a Petersburgiem nie stoi Białystok czy Grodno, a o losach wsi Opaka Duża decyduje sam Stalin. 
dwa sąsiednie mocarstwa" ${ }^{41}$, jak też do komisarza polskiej policji, tropiącego Białorusinów: „Tak właśnie przechodzi się do historii w małych miasteczkach - trwając w jednym miejscu i tworząc rzeczy niekoniecznie piękne, ale przydatne wszędzie i każdemu" ${ }^{42}$. Nie chodzi tu bynajmniej o konformizm czy tchórzostwo, ale właśnie o etos trwania i wierności miejscu. We właściwy sobie, nieco przewrotny sposób Androsiuk sygnalizuje też „przydatność” peryferii centrom i imperiom, ich wzajemne warunkowanie się.

Okazuje się, że to właśnie miejsce staje się dla Androsiuka najważniejszym nośnikiem pamięci i ostoją tożsamości. Jak zauważa Helena Duć-Fajfer:

Nigdzie tak głęboko jak na pograniczach nie ujawnia się zmienność konstelacji kulturowych, które stanowią, mówiąc przenośnie, wiele hipostaz bytów podstawowych, ale linia tożsamości miejsca, w którym gruntują się te przemiany, jest uchwytna nawet $\mathrm{w}$ antytezach czy nicowaniu ${ }^{43}$.

Różnego typu związki pamięci i miejsca to leitmotiv badań „pamięciologicznych" oraz, według Sławomira Kapralskiego ${ }^{44}$, jeden z symptomów ponowoczesności, na pograniczu mają one jednak szczególną rangę.

Zmienia się Historia, języki, „,konstelacje kulturowe”, a Miasteczko trwa. Narrator czyni wiele, by zasugerować nam jego osadzenie niejako poza czasem, monotonną, niezmienną, ale być może właśnie dlatego gwarantującą przeżycie, egzystencję. Zastanawiające jest również, że charakteryzując lokalną pamięć, Androsiuk sięga po obrazowanie z zakresu codzienności, po mowę ciał i przesyconych sensualizmem opisów ubrań:

Z przeszłością jest jak z ubraniami. Jedni mają ich wiele i zmieniają garnitury co miesiąc, te trochę tylko podchodzone odkładają do szafy, albo wynoszą na śmietnik, i natychmiast wyrzucają z pamięci te wszystkie desenie i prążki, i oddają $w$ zapomnienie chłodny szelest bistoru, i ciepły dotyk prawdziwej wełny. Jeszcze inni $\mathrm{w}$ jednym garniturze chodzą przez lata. Znają na pamięć każde zadrapanie na marynarce i potrafią opowiedzieć historię każdej plamki na spodniach ${ }^{45}$.

\footnotetext{
41 Tamże, s. 22.
}

42 Tamże, s. 25.

${ }^{43}$ H. Duć-Fajfer, Pomiędzy bukwa a literą. Wspótczesna literatura mniejszości białoruskiej, ukraińskiej i łemkowskiej w Polsce, Kraków 2012, s. 142.

$44, \ldots[.$.$] rozmaite formy pamięci wyzwalają się spod dominacji historii jako autorytatywnej$ wersji przeszłych wydarzeń, wspartej państwowym systemem edukacji, oficjalnymi rytuałami i kontrolą dyskursów dotyczących przeszłości. Pozbawione oparcia w oficjalnych chronologiach, pamięci te coraz częściej zwracają się do miejsc i przestrzeni w poszukiwaniu inspiracji i symbolicznej reprezentacji" [S. Kapralski, Pamięć, przestrzeń, tożsamość. Próba refleksji teoretycznej, w: Pamięć, przestrzeń, tożsamość, red. S. Kapralski, Warszawa 2010, s. 26].

45 M. Androsiuk, Wagon drugiej klasy, s. 56-57. 
Wykorzystuje również metaforykę przestrzenną - przestrzeń budowana jest tu niemal na wzór opisanych przez de Certeau "sztuk działania”, porządkujących rzeczywistość, a detaliczna enumeracja utrwala obraz świata, tak znany, że umykający postrzeganiu:

Nasze miejscowe pociągi przybywają na dworzec anonimowo i nikt ich nie czeka. Do znudzenia powtarzają jeden i ten sam szlak, codziennie przywożą tych samych ludzi, a ci ludzie już na pamięć znają każdą kostkę na peronie, każdą ścieżkę do miasta, każdy krzak i każde drzewo przy ścieżce, i każdy liść na tym drzewie. Więc, nie tracąc czasu, nie rozglądają się na cztery strony świata, wysiadają z wagonów i rozchodzą się każdy w swoim kierunku. [...] Czasem mam wrażenie, że całą naszą okolicę ubiera jeden krawiec. [...] siada przy starej maszynie i w nieskończoność powtarza wzory i fasony wyuczone w młodości ${ }^{46}$.

Z pozoru mamy tu do czynienia wyłącznie z krytyczną refleksją na temat małomiasteczkowego marazmu, $\mathrm{w}$ tych opisach kryje się jednak sugestia, że pamięć może być przechowywana także w obszarach pozasłownych, trwać niejako w utajeniu, by w odpowiednim momencie wybrzmieć jako przeciw-historia - ta, by wejść w jakąkolwiek relację z Historią, musi bowiem zostać opowiedziana. Jak pisze Kołodziejczyk, nawiązując do rozważań Dipesha Chakrabartego:

Historia, jako jedna z możliwych narracji ,ja” i wspólnoty, jest jednocześnie narracją jedyną możliwą, czyli metanarracją wyznaczającą warunki uhistorycznienia. Jednak to, co nie zyskuje $\mathrm{w}$ badaniach historycznych statusu historycznego czy historyczności, nie znika. Jako druga strona historii, niehistoryczność, a raczej historyczność niekompletna i niedoskonała (niedostatecznie nowożytna, nienowoczesna, nieświecka, niewystarczająco racjonalna), utrzymuje się na marginesie historii jako przeszłość podrzędna, oparta na formach pamięci, które czasami są świadomie antyhistoryczne i stanowią przestrzeń różnicy wobec historii ${ }^{47}$.

Paradoksalnie, taką formą pamięci może być też milczenie. Ten wątek pojawia się w kryminale Katarzyny Bondy Okularnik ${ }^{48}$, gdzie czytamy: „Ludzie przez lata zawieruch dziejowych nauczyli się tutaj głośno milczeć”, ,Biało-

\footnotetext{
46 M. Tamże, s. 69.

47 D. Kołodziejczyk, Postkolonialne odzyskiwanie pamięci: zawłaszczenia, fabulacje, niesamowite odpominanie, s. 281-282.

48 Autorka sięga po historię mordów dokonanych przez oddział „Burego” w 1946 na prawosławnej ludności podlaskich wsi, budując intrygę, z której wynika, że tamte wydarzenia do dziś kształtują losy mieszkańców Hajnówki, mają wpływ na lokalną władzę czy sferę biznesu, trzymające się nawzajem w szachu wiedzą o zbrodni, jej wykonawcach i ofiarach.
} 
rusini pamiętają w cichości" ${ }^{49}$. Zamiast słów przemawiają kości, groby, emocje, np. odziedziczony po przodkach strach ${ }^{50}$. Nośność milczenia jako formy pamięci jest jednak ograniczona $\mathrm{w}$ czasie, obejmującym, jak sądzę, zakres oddziaływania pamięci komunikacyjnej (w rozumieniu Aleidy Assmann), w której zachowana zostaje łączność pokoleniowa. Zbyt długie milczenie może doprowadzić do całkowitego zapomnienia. Wtedy ratunkiem mogą się okazać np. zapomniane/utajnione archiwalia czy badania archeologiczne.

Michał Androsiuk, urodzony na Podlasiu Białorusin, nie milczy, tylko opowiada - to historie subtelne, metaforyczne, przewrotne, w których nie mówi się wprost o najtrudniejszych elementach dawnych i obecnych relacji polsko-białoruskich. Zapytany o to, dlaczego nie dotyka w swojej prozie newralgicznych tematów, np. wydarzeń z 1946 roku, stwierdza - dopiero mam zamiar $^{51}$. Najwyraźniej zatem wymagają one zarówno adekwatnej, wystarczająco długo dojrzewającej formy, jak też odpowiedniego czasu. W polemice, jaką podjęłyśmy (oprócz piszącej te słowa - Katarzyna Niziołek i Danuta Zawadzka) z reportażem Marcina Kąckiego Białystok. Biała siła, czarna pamięć (Wołowiec 2015), nadając jej postać tez zachęcających białostoczan do podjęcia dyskusji zarówno na temat samej książki, jak też własnej zbiorowej kondycji, zwarte zostało m.in. takie stwierdzenie:

Wydaje się, że wobec złożonej historii naszych [podlaskich - dop. K.S.M.] ziem i związanej z nimi nierozstrzygalności konfliktu pamięci (dotyczy to nie tylko relacji polsko-żydowskich, ale też polsko-białoruskich) właśnie literatura stanowi najbardziej adekwatne narzędzie/medium ich reprezentacji. Dzieje się tak dlatego, że operując szeregiem środków - symbolem, metaforą, wyobraźnią, fikcją - pozwala opowiedzieć o rzeczach najtrudniejszych (więcej nawet - pośrednio ich doświadczyć), ale nie udziela jednoznacznych odpowiedzi, o niczym nie przesądza, niczego nie rozstrzyga. Podlaska realność (być może na tym polega specyfika naszego regionu) wybrzmiewa zatem najpełniej przefiltrowana przez materię literacką, z założenia problematyzującą kwestie reprezentacji czy pamięci (zbiorowej i indywidualnej) ${ }^{52}$.

49 K. Bonda, Okularnik, Warszawa 2015, s. 542; 623.

50 W naturalny sposób pojawia się tu wątek post-pamięci, nie będę go jednak rozwijać, gdyż temat ten nie odnosi się do stanowiącej główny przedmiot rozważań prozy Androsiuka.

51 Zob. relacja ze spotkania autorskiego z Michałem Androsiukiem, które odbyło się 9.10.2015 r. w Białymstoku w ramach 6 edycji Festiwalu Literackiego „Zebrane”, zorganizowanego przez Stowarzyszenie „Fabryka Bestsellerów”. Rozmowę prowadziła Katarzyna Sawicka-Mierzyńska, https://www.youtube.com/watch?v=Pz7EDn9vR3Y [dostęp 7.05.2016].

${ }^{52}$ K. Niziołek, K. Sawicka-Mierzyńska, D. Zawadzka, Oto czym jesteśmy/jesteście. Zrozumieć Białystok, http://filologia.uwb.edu.pl/zbr/zbz.pdf [dostęp 07.05.2016]. Debata o książce odbyła się na Uniwersytecie w Białymstoku 21.01.2016 r. Jej zapis można znaleźć pod adresem: http://fundacja.uwb.edu.pl/images/ZapisDebaty.pdf [dostęp 07.05.2016]. 
Milczenie (traktowane tu jako metonimia niepamięci, ale też „forma przetrwalnikowa" pamiętania, stąd jego ambiwalencja) przerwane zbyt gwałtownie, w nieodpowiednim czasie, przez osoby, którym przyświecają nieczyste intencje, może danej społeczności bardziej zaszkodzić, niż pomóc, nie rozładowuje napięć, tylko wzmacnia antagonizmy - do takich wniosków doszłyśmy podczas wielogodzinnych dyskusji nad podlaską tożsamością. Zupełnie inaczej rzecz się ma w przypadku prozy Michała Androsiuka.

Hajnówka i jej przeszłość pojawiają się nie tylko w omówionych wyżej utworach. Na osobną uwagę zasługuje wspomniany już Okularnik Katarzyny Bondy (wątek kryminalny wydaje się tu jedynie pretekstem do zarysowania bardzo wyrazistego obrazu miasta), gdzie obok bohaterów fikcyjnych bez trudu można rozpoznać zaczerpnięte z rzeczywistości postaci białoruskich aktywistów czy polskich nacjonalistów. Książka, której akcja toczy się w kilku płaszczyznach czasowych, ma bardzo osobisty wymiar. Autorka nawiązuje do odkrytej dopiero w dorosłym życiu rodzinnej historii - jedną z ofiar „Burego" była jej babcia ${ }^{53}$. Interesujące, ze względu na relację pamięć indywidualna - dzieje małej społeczności - Wielka Historia wydają się też Hajnowskie wspomnienia. Pożegnanie przeszłości Władysława Zina (Hajnówka 2010). Osobny wątek to reporterskie relacje, w których Hajnówka, znowu głównie w kontekście wydarzeń 1946 r., ukazana jest z perspektywy zewnętrznej - wzmiankowany już reportaż Marcina Kąckiego oraz książka Jutro spadna gromy (Białystok, 2015) autorstwa Bartosza Jastrzębskiego i Jędrzeja Morawieckiego, z fotografiami Macieja Skawińskiego. Obie ilustrują bezradność reportażystów wobec tej tematyki, tyle że Marcin Kącki wykazuje się brakiem świadomości własnych ograniczeń, sytuując się w podwójnej roli śledczego i rewelatora ukrywanych latami prawd, zaś autorzy Jutro spadna gromy zarówno własną bezradność, jak też nierozstrzygalność lokalnych konfliktów pamięci tematyzują. Na koniec warto też przywołać poezję Białorusinki średniego pokolenia, urodzonej w Hajnówce Ireny Stelmach (rocznik 1975), która $\mathrm{w}$ jednym $\mathrm{z}$ wierszy pisze:

Stać mnie jedynie na małą ojczyznę, na moje miasto, gdzie nic nie zaskoczy. Poczta, w której sprzedają nasiona i buty, konewki pełne malin na środku chodnika.

Ten arbitralny skrawek i tak aż zanadto ciąży.

Wciąż trzeba oswajać, wmawiać sobie,

53 Zob. m.in. My ze spalonych wsi, z Katarzyną Bondą rozmawia P. Smoleński, "Gazeta Wyborcza" 22.02.2016, http://wyborcza.pl/magazyn/1,150990,19645068,katarzyna-bonda-my-zespalonych-wsi.html [dostęp 07.05.2016]. 
że nóż nie tylko kroi chleb, ale też zabija.

Że jeżeli dziewczyny się gwałci to tak było zawsze

i żadna w tym skaza wieku.

[...]

Stać mnie jedynie na własne cierpienie.

Moje pokolenie wie, że serce nie jest jak wór,

z ledwością mieści lokalność.

Nie ma miejsca na zakurzone sentymenty przodków,

kresowe wzruszenia.

Nigdy nie napiszę na murze:

ODDAJCIE NAM WILNO I LWÓW

Patriotyzm pachnie archaizmem,

chorobliwie rozszerza naczynia krwionośne.

Jedynie mitomani wiozą w autokarach

słodki cud wspomnień i płaczą ${ }^{54}$.

Pojawia się tu obraz Historii - balastu, przeszłości, która ciąży, o której lepiej zapomnieć, wybierając życie. Szczegółowe omówienie przywołanych utworów wymagałoby znacznie obszerniejszego artykułu, dlatego zostają tu zaledwie wymienione jako przyczynek do dalszych badań.

\section{"Each Family Needs a Name and a Past" - Remembering and Forgetting in Literary Representation of Hajnówka in Michał Androsiuk's Fiction}

\section{Summary}

The article offers the reading of Michał Androsiuk's Biały kon, Wagon drugiej klasy in the context of remembrance, addressing the question of identity of Belarusians in Podlasie region. A borderland town of Hajnówka becomes the place where individual and collective memory, History, and imagination intersect. Finally, it appears that the long-lasting cohesive national identity, while grounded on false premises, might prove to be more tempting or convenient than the complex, equivocal frontier past.

Keywords: memory, identity, Belarusians, borderland, Podlasie, Michał Androsiuk

\footnotetext{
${ }^{54}$ I. Stelmach, [Stać mnie jedynie na małą ojczyznę...], w: tejże, Retrospekcje, Białystok 2003, s. 26.
} 